\title{
Esophageal, Fecal and Exclosure Estimates of Cattle Diets on a Longleaf Pine-Bluestem Range
}

\author{
MARK K. JOHNSON AND HENRY A. PEARSON
}

\begin{abstract}
Microhistological analysis of esophageal or fecal materials provides an accurate and efficient method for evaluating botanical compositions of cattle diets on native longleaf pine-bluestem range. For practical purposes fecal analysis is the preferred method. Plant species that were most important to cattle during the present study were the bluestems and panicums.
\end{abstract}

Southern pine ecosystems serve as range for livestock and wildlife. These forest ranges have potential for high production of red meat with minimum inputs (Pearson and Whitaker 1974; Pearson 1975; Sternitzke and Pearson 1975). Cattle impact on ecosystems is related to the animal's dietary needs, preferences, and available forage.

The purpose of this study was to estimate cattle diets on longleaf pine-bluestem range. Specific objectives were to contrast cattle diets estimated from esophageal and fecal samples with estimates obtained from exclosures.

\section{Study Areas}

This study was conducted from April 1971 through March 1974 on the Palustris Experimental Forest in central Louisiana. A stand of second growth longleaf pine (Pinus palustris) $(\simeq 15$-years-old) existed on the area. Predominant herbaceous vegetation was pinehill bluestem (Andropogon scoparius). Other bluestem grasses were prominent, as were the panicums (Panicum spp.) and paspalums (Paspalum spp.). Principal browse included southern waxmyrtle (Myrica cerifera), oaks (Quercus spp.), blackberries (Rubus spp.), and blueberries (Vaccinium spp.).

\section{Methods and Procedures}

Range utilization and production were determined by a paired plot technique similar to the plucked quadrat method (Grelen 1967). Sixty pairs of quadrats $\left(\simeq 1 \mathrm{~m}^{2}\right.$, one in an exclosure, one grazed) were randomly established throughout the range. Quadrats were paired on the basis of herbage composition. Herbage in each exclosure was plucked to the height of plants in quadrats that were grazed and was oven-dried to a constant weight. The clippings from each plant species were weighed and clippings from all species were mixed together to simulate a cattle diet. Since the actual dry weight compositions of these mixtures were known, they were used as quality control samples to test technician accuracy during microscopic analysis.

In March 1971, esophageal and rumen fistulas were installed in

The authors are assistant professor, Department of Wildlife and Fisheries, Mississippi State University, Mississippi State, Miss. 39762; and chief range scientist Southern Forest Experiment Station, U.S. Department of Agriculture, Forest Service, Alexandria, Louisiana 71360.

Authors thank Helen Wofford for technical assistance in the laboratory. Harry Jacobson provided some of the reference materials used during the study. This research was conducted under Cooperative Agreement No. 19-276 between the Southern Forest Experiment Station and Mississippi Agricultural and Forestry Experiment Station.

Manuscript received October 1, 1979. crossbreed Brahman heifers. Samples of forage were collected from esophageal fistula on three consecutive days at monthly to bimonthly intervals for the grazing seasons of 1971-1973. Due to fistula problems one of the animals was omitted from the study after the first collected period and only two esophageal fistulated cattle were used for the remainder of the study. The fistulated cattle were allowed to graze freely for about $1 \mathrm{hr}$ or until 3-4 liters of forage had collected in fistula bags; grazing began about 7 a.m. on each collection day. Fecal samples were taken by rectal palpations from six intact animals during the first year; only three of the animals were used in subsequent years, and sampling was done to coincide with esophageal collections. Esophageal and fecal samples were oven-dried and ground through a $1-\mathrm{mm}$ screen. Individual samples were analyzed to study variation among cows and days. Each collection period, subsamples were composited to make one sample for all cows and all days.

Diet and quality control samples were analyzed by a microscope method (Sparks and Malechek 1968). Five slides were prepared and 20 fields were quantified for each slide so that a total of 100 fields were quantified for each sample. About 6 months training and development of reference plant materials were necessary prior to diet sample evaluations. Known mixtures prepared from exclosure clipping were used as quality control samples. Data were compared using Kulczynski's similarity index and correlation procedures (Johnson 1979). Similarity indices were treated as normally distributed, independent variables. Results reported here as means $\pm \mathrm{SE}$.

\section{Results and Discussion}

Cattle consumed large amounts of grasses and more than $50 \%$ of all diets were bluestems (Table 1). It was not possible to distinguish different bluestems from each other by microscope analysis. Because we usually observed cattle taking pinehill bluestem and since it is very abundant in comparison to other bluestems, we believe that pinehill bluestem makes up most of this category. Panicums were the second most important diet category, making up about $10 \%$ of the dry matter ingested. A large variety of browse and forbs were taken in small amounts.

Pine needles constituted more than $8 \%$ of fecal materials but were probably over-estimated. The coarse textured, highly suberized needles are readily recognized in fecal samples compared to fragments from most plants.

There were certain other differences in esophageal compared to fecal samples. Esophageal samples were cleaner and less digested so that plant fragments were easier to identify. A few forbs that were in the esophageal samples were not detected in fecal samples but fragments of plants that made up as little as $1 \%$ of esophageal contents were recognizable after digestion.

Compositions of test mixtures were estimated within $5 \%$ for individual plants and the total difference between plants in any test mixture and a technician's estimate of the percentages for all the 
Table 1. Average (X士 $\mathrm{SE})$ estimates of a cattle dietary composition (\%) on longleaf pine-bluestem range in central Louisiana. Estimates wer e obtained by examination of exclosures, and esophageal and fecal samples.

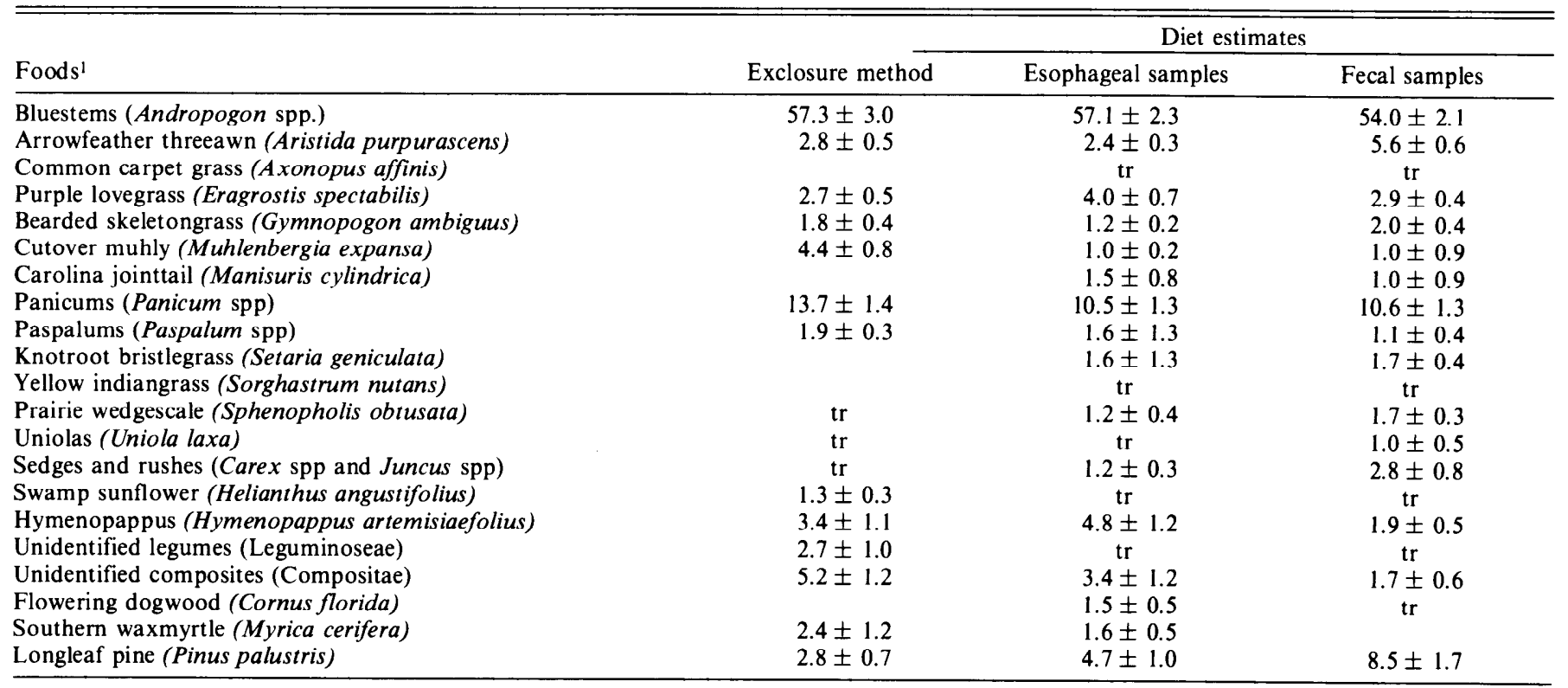

IOther plants identified in trace $(<1 \%$ ) amounts were: pineywoods dropseed (Sporobolus junceus), purpletop tridens (Tridens flavus), showy partridgepea (Cassia fasciculata), littleleaf tickclover (Desmodium ciliare), daisy fleabane (Erigeron strigosus), white eupatorium (Eupatorium album), southern brackenfern (Pteridium aquilinum), slender rosinweek (Silphium gracile), pencilflower (Stylosanthes biflora), Virginia tephrosia (Tephrosia virginiana), American beautyberry (Callicarpa americana), Japanese honeysuckle (Lonicera japonica), oaks (Quercus spp.), poison-ivy (Rhus radicans), blackberry (Rubus spp.), sassafras (Sassafras albidum), greenbriers (Smilax spp.), huckleberry (Vaccinium spp.), summer grape (Vitis aestivalis), and unidentified grasses and browse.

species in any mixture was never greater than $10 \%$. Microscopic estimates from quality control samples were highly $(87 \pm 1 \%)$ similar to the actual exclosure clippings and estimates of botanical composition were significantly correlated $(p<0.05)$ with actual dry weight compositions (Table 2). This supports the hypothesis that all plants eaten by cattle were detected in esophageal or fecal samples; and the proportions of plants were accurately estimated. Diets were $72 \pm 4 \%$ similar among cows and $68 \pm 2 \%$ similar among days. The high similarities observed in these comparisons suggests that the number of days and/or cows used in the study were sufficient for extrapolating results to a larger population.

Estimates from esophageal and fecal samples were about $90 \%$ similar but each of these diet estimates was less than $80 \%$ similar to data obtained from exclosures. Regardless of the technique, all three diet estimates were highly correlated $(r=0.99)$. Exclosures provide data on plants removed by all herbivores in an ecosystem so that data are not representative of cattle diets alone. Utilization is difficult to detect when it is light (Smith and Shandruk 1979). Data obtained here were reasonable estimates of cattle diets because utilization was heavy.

Reasons for doubting the accuracy of diet estimates obtained from fecal analysis have been recently, adequately stated (Smith and Shandruk 1979). Smith and Shandruk (1979:279) said that more work was needed before fecal analysis could be evaluated as a technique for quantifying ruminant diets even though their pooled estimates of rumen and fecal contents were more than $85 \%$ similar. There is considerable controversy over the accuracy of fecal analysis to the point that persons on both sides of the issue hold on to their prejudices regardless of the body of data available, even if it is their own. However, reliable data can be obtained from fecal analysis in spite of these criticisms when technicians are carefully trained (Johnson 1979).

Microscope analysis of botanical compositions is as much an art as it is a science. Technicians must be trained in a program designed to build their confidence and skills for accurately quantifying compositions of mixtures. We know of no investigators with carefully trained technicians who reported an inability to find plants in feces that made up significant proportions of an animal's diet, and results have been within reasonable limits (Free et al. 1979; Voth and Black 1973; Anthony and Smith 1974; Dearden et al. 1975). In addition, our results demonstrate the technicians can be trained to accurately estimate compositions of plant mixtures when grasses and different forbs (which may fragment in different ways) are found in the same mixtures.

For the practical purposes of sampling without killing animals and avoiding the problems associated with utilization techniques, fecal analysis is the superior method for estimating diets of herbivores. 
Table 2. Botanical compositions (\%) of quality control mixtures (A) compared to estimated compositions obtained by microhistological analysis. (B).

\begin{tabular}{|c|c|c|c|c|c|c|c|c|c|c|}
\hline \multirow[b]{2}{*}{ Plant taxa } & \multicolumn{2}{|c|}{ June 1971 } & \multicolumn{2}{|c|}{ July 1971} & \multicolumn{2}{|c|}{ Sept 1971} & \multicolumn{2}{|c|}{ Dec 1971 } & \multicolumn{2}{|l|}{ Jan 1972} \\
\hline & A & B & A & B & A & B & A & B & A & B \\
\hline Bluestems & 79 & 74 & 67 & 61 & 44 & 44 & 62 & 60 & 46 & 50 \\
\hline Panicums & $\operatorname{tr}$ & 4 & 8 & 8 & 8 & 7 & 16 & 17 & 11 & 15 \\
\hline Paspalums & 2 & 2 & 3 & 3 & 2 & 1 & & 2 & $\operatorname{tr}$ & $\operatorname{tr}$ \\
\hline Cutover muhly & 7 & 6 & 1 & 3 & & 1 & 6 & 6 & 13 & 10 \\
\hline Other grasses & 2 & 4 & 9 & 12 & 31 & 22 & 11 & 7 & 22 & 19 \\
\hline Grasslikes & & & & & & & & $\operatorname{tr}$ & $\operatorname{tr}$ & 1 \\
\hline Composites & 4 & 5 & 6 & 12 & 8 & 20 & 3 & 5 & 7 & 9 \\
\hline Legumes & 4 & 5 & 2 & 1 & 1 & & $\operatorname{tr}$ & 1 & & 2 \\
\hline Other forbs & 2 & & 4 & & 6 & & 2 & & & \\
\hline \multirow[t]{2}{*}{ Pine } & & & & & & 5 & & 2 & 3 & \\
\hline & \multicolumn{2}{|c|}{ Mar 1972} & \multicolumn{2}{|c|}{ May 1972} & \multicolumn{2}{|c|}{ June 1972} & \multicolumn{2}{|c|}{ Aug 1972} & \multicolumn{2}{|c|}{ Sept 1972} \\
\hline Bluestems & 25 & 24 & 68 & 52 & 71 & 64 & 49 & 44 & 47 & 48 \\
\hline Panicums & 30 & 20 & 6 & 12 & 5 & 9 & 6 & 11 & 7 & 6 \\
\hline Paspalums & 0 & 3 & 2 & 3 & 2 & 1 & 1 & 1 & $\operatorname{tr}$ & 4 \\
\hline Cutover muhly & 16 & 14 & 2 & 4 & 2 & 3 & 2 & 3 & 4 & 1 \\
\hline Other grasses & 4 & 8 & 9 & 10 & 7 & 11 & 15 & 19 & 23 & 27 \\
\hline Grasslikes & 5 & 1 & 1 & 3 & $\operatorname{tr}$ & 1 & & & & $\operatorname{tr}$ \\
\hline Composites & 20 & 25 & 7 & & 10 & 11 & 15 & 21 & 14 & 14 \\
\hline Legumes & & 1 & 5 & 3 & 0 & 12 & 1 & 5 & $\operatorname{tr}$ & \\
\hline Other forbs & & & & 4 & & & & & & \\
\hline
\end{tabular}

Pine

Bluestems
Panicums
Paspalums
Cutover muhly
Other grasses
Grasslikes
Composites
Legumes
Other forbs
Pine

$\begin{array}{rrrr}54 & 42 & 42 & 39 \\ 10 & 15 & 21 & 20 \\ 4 & 6 & 2 & \\ 17 & 18 & 24 & \\ 14 & 14 & 11 \\ 1 & 3 & \end{array}$

39

20

2

2
16

16

1
18

2

5

Sept 1973

Dec 1973

$\begin{array}{lrrrr}\text { Bluestems } & 37 & 33 & 38 & 44 \\ \text { Panicums } & 12 & 19 & 22 & 23 \\ \text { Paspalums } & 3 & 2 & \operatorname{tr} & 1 \\ \text { Cutover muhly } & 2 & 3 & 4 & 7 \\ \text { Other grasses } & 20 & 24 & 18 & 8 \\ \text { Grasslikes } & & \operatorname{tr} & & \\ \text { Composites } & 18 & 17 & 14 & 8 \\ \text { Legumes } & 8 & 2 & 4 & 4 \\ \text { Other forbs } & & & & \\ \text { Pine } & & & & 5\end{array}$

\section{Literature Cited}

Anthony, R.G., and N.S. Smith. 1974. Comparison of rumen and fecal analysis to describe deer diets. J. Wildl. Manage. 38:535-540.

Dearden, B.L., R.M. Hansen, and R.E. Pegau. 1975. Precision of microhistological estimates of ruminant food habits. J. Wildl. Manage. 39:402407.

Free, J.C., R.M. Hansen, and P.L. Sims. 1970. Estimating dry weights of food plants in feces of herbivores. J. Range Manage. 23:300-302.

Grelen, H.E. 1967. Comparison of cage methods for determining utilization of pine-bluestem range. J. Range Manage. 20:94-96.

Johnson, M.K. 1979. Foods of primary consumers on cold desert shrubsteppe of southcentral Idaho. J. Range Manage. 32:365-368.

Pearson, H.A. 1975. Herbage disappearance and grazing capacity determination of southern pine bluestem range. J. Range Manage. 28:71-73.
Pearson, H.A., and L.B. Whitaker. 1972. Thrice-weekly supplementation adequate for cows on pine-bluestem range. J. Range Manage. 23:315316.

Pearson, H.A., and L.B. Whitaker. 1974. Yearlong grazing of slash pine ranges: effects on herbage and browse. J. Range Manage. 27:195-197.

Smith, A.D., and L.J. Shandruk. 1979. Comparison of fecal, rumen and utilization methods for ascertaining pronghorn diets. J. Range Manage. 32:275-279.

Snedecor, G.W., and W.G. Cochran. 1973. Statistical Methods. Iowa State Univ. Press, Ames. 593 p.

Sparks, D.R., and J.C. Malechek. 1968. Estimating percentage dry weight in diets using a microscope technique. J. Range Manage. 21:203-208.

Sternitzke, H.S., and H.A. Pearson. 1975. Forest-range resources of southwest Louisiana. J. Range Manage. 28:264-266.

Voth, E.H., and H.C. Black 1973. A histologic technique for determing feeding habits of small herbivores. J. Wildl. Manage. 37:223-231. 